\title{
An Exploratory Study Examining Barbadian Students' Knowledge and Awareness of Costs of University of the West Indies Education
}

\author{
Nadini Persaud ${ }^{1} \&$ Indeira Persaud $^{2}$ \\ ${ }^{1}$ Department of Management Studies, Faculty of Social Sciences, University of the West Indies, Cave Hill Campus, St. \\ Michael, Barbados. \\ 2 Department of Psychology, Division of Arts, Science, and General Studies, St. Vincent and the Grenadines \\ Community College, Villa Campus, St. Vincent. \\ Correspondence: Nadini Persaud, Department of Management Studies, Faculty of Social Sciences, University of the \\ West Indies, Cave Hill Campus, St. Michael, Barbados. Tel: 1-246-417-4295.
}

Received: October 20, 2015

Accepted: December 3, 2015

Online Published: December 10, 2015

doi:10.5430/ijhe.v5n2p1

URL: http://dx.doi.org/10.5430/ijhe.v5n2p1

\begin{abstract}
This study explores Barbadian students' knowledge/awareness on various facets of costs associated with their University of the West Indies (UWI) education and student perceptions of State funded education. The study was conducted subsequent to the announcement of UWI tuition fees which came into effect in September 2014. Ninety-three Faculty of Social Sciences (FSS) students participated in the study. The research highlighted that:- (1) FSS students have serious gaps in knowledge regarding their UWI education costs, (2) many FSS students are motivated to work harder at their studies when studies are personally self-financed, (3) FSS students associate opportunity costs with lost income, lost time with family/friends, and lost leisure opportunities with their UWI studies, and (4) FSS students perceive that the Government of Barbados (GOBD) incurs an opportunity cost by financing UWI education. The paper concludes by discussing implications for policy and practice.
\end{abstract}

Keywords: University of the West Indies, Barbados, Students, Perceptions, Costs, Opportunity Costs, Education

\section{Introduction}

The ongoing debate over the last ten years about the increasing costs of tertiary education in Barbados, especially costs associated with University of the West Indies (UWI) education — and Government's ability to sustain this cost - has met with a fair degree of criticism by the Barbados populace. Although some Barbadians acknowledge that perhaps the time has arrived for tertiary education to be self-financed by Barbadians desirous of pursuing UWI education, many Barbadians still hold the philosophical view that charging for tertiary education will create social inequity in Barbados and that the poor would be further disenfranchised. During the past two years, the debate on costs of UWI education has intensified considerably as a result of the Government's announcement in August 2013 about payment of tuition fees by Barbadian students. In light of the media publicity that has been taking place on the cost of UWI education and its cost implications for Barbadian students, we felt that it was timely to conduct an exploratory study to gauge Barbadian student knowledge and awareness on costs associated with their UWI education.

Two fundamental considerations underpin our study on Barbadian student knowledge and awareness on costs associated with their University studies. The first pertains to the theoretical contribution of our study to the global body of literature on this topic. Previous research on this topic have been conducted using pre-university students and their parents rather than actual university students. Additionally, to the best of our knowledge, no published research exists on this topic from the Caribbean. Our study is therefore quite unique since it uses actual university students, and was conducted in a small developing country in the Caribbean region. Moreover, contrary to previous research, our students' perceptions were assessed in an environment of low user fees since students have to pay only $20 \%$ of the full cost of their UWI education. Our second contribution pertains to policy and practice in the Barbadian society. Our research should be of interest to several stakeholder groups including UWI administration and the GOBD in crafting policies to educate Barbadians about the value of a tertiary education. 
These considerations give rise to our 6 research questions (RQ):-

RQ1 How knowledgeable are FSS Barbadian students' about the cost of their UWI education?

RQ2 What are FSS Barbadian students' perception regarding GOBD obligation to fund UWI education?

RQ3 To what extent are FSS Barbadian students motivated to work harder at their studies given the level of investment by GOBD in their UWI education?

RQ4 To what extent are FSS Barbadian students motivated to work harder at their studies if UWI education were personally self-financed?

RQ5 What are FSS Barbadian students' perceived personal opportunity costs associated with pursuing UWI education?

RQ6 Do FSS Barbadian students perceive that GOBD incurs an opportunity cost by sponsoring their UWI education?

Our paper is structured as follows: Section one provides contextual information for the study and a brief literature review; section two explains the research methodology employed for the study; section three analyses and discusses the findings from this study, and the final section concludes the study by documenting the conclusions, implications for policy and practice, and limitations/suggestions for future research.

\section{Understanding the Local Context}

\subsection{Overview of the Education System in Barbados}

Barbados - a sovereign developing country - boasts one of the highest literacy rates (99.6\%) globally (Central Intelligence Agency, 2014). This remarkable literacy accomplishment has been achieved as a result of successive government support/commitment to the education sector through substantial public subsidization of education (Griffith, 2001) including university education, and reflects the Government's priority in using education as a tool for social change (United Nations International Bureau of Education, 2014). The philosophy underpinning education in Barbados can be traced back to the early 1960s and is rooted in the belief that "every child should have educational opportunities of a kind which would allow him to make the most of his abilities and to contribute to the social and economic growth of the country" (Ministry of Education, Science, Technology and Innovation, 2000, p. 31).

Today, the Government's commitment to free education for all Barbadians citizens at all levels of the social spectrum is embodied in its 2002 Education Policy Act, Chapter 41: I52 under the caption "Free Public Education" (Ministry of Education, Science, Technology and Innovation, 2002), documented in various Ministry of Education, Science, Technology and Innovation documents, and proudly displayed on various government websites, including, the website of the Barbados Tourism Encyclopedia (2014) which states "......the Barbados Government pays the cost of education of Barbadian students at primary, secondary and tertiary levels...." (II 1).

\subsection{Government Policy Regarding UWI Fees for Barbadian Students}

Barbados is one of the few countries globally where university education was free of cost to Barbadian citizens until the academic year 2014-2015. This allowed Barbadian students to simply register for courses at the UWI without having to necessarily note the breakdown of university fees or even the total amount that GOBD paid per student. This however changed on August 13, 2013 when it was formally announced in Parliament that students will be responsible for $20 \%$ of their fees.

Effective 2014 Barbadian citizens pursuing studies at campuses of the UWI will be required to pay tuition fees from academic year 2014/2015 while the Government will continue to fund economic costs. (Sinckler, 2013, p. 80)

GOBD noted that this policy had been necessitated as a result of the exponential costs of university education which Government could no longer sustain (Sinckler, 2013). Table 1 shows the revised UWI fee structure for students pursuing undergraduate degrees at the Cave Hill Campus. 
Table 1. Costs Associated with a UWI Undergraduate Degree ${ }^{1}$

\begin{tabular}{lcc}
\hline Faculty & $\begin{array}{c}\text { Annual Tuition Cost } \\
\text { Paid by Full-Time Student }\end{array}$ & $\begin{array}{c}\text { Annual Economic Cost } \\
\text { Paid by Government }\end{array}$ \\
\hline & Barbados $\$^{2}$ & Barbados $\$$ \\
Humanities \& Education & 5,625 & 28,125 \\
Law & 8,808 & 44,040 \\
Science \& Technology & 5,625 & 28,125 \\
Social Sciences & 5,625 & 28,125 \\
Medicine - Clinical & 16,618 & 83,090 \\
Pre-Clinical & 65,000 & \\
\hline
\end{tabular}

Source: 2013 Financial Statement and Budgetary Proposals, p. 80.

${ }^{1}$ Undergraduate degrees are 3 years

${ }^{2}$ US $\$ 1=$ Barbados $\$ 2$

\subsection{Public Commentary/Publicity on Costs of UWI Education}

Commentary regarding costs of UWI education in Barbados has been a topic of discussion from as early as the 2000s when predictions were made by two prominent Barbadian economists - both former Central Bank Governors - that fully funded UWI education was no longer sustainable for Barbados. In 2004, Dr. Marion Williams questioned whether university-free education could survive and "whether the consumers of education should be asked to bear some or a higher proportion of the needed outlays" (Williams, 2004, p. 27). Williams pointed out that Government funds always have numerous competing demands, and that if reduction in education expenditure was necessitated, then University education should be the logical budget line item to be reduced. Similar predictions were again made in 2006, this time by Sir Courtney Blackman who posited that the era for fully funded university education was over, noting that "the shortfall will have to be met by modest increases in student fees, endowments by corporations and elsewhere" (Blackman as cited by Alleyne, 2006, II7).

During 2013-2014, commentary on cost of university education intensified considerably. The reality that University education was no longer completely free triggered nationwide press attention, commentary, and debate in a variety of mediums including Parliament, local and regional newspapers, radio talk shows, television news, facebook, and twitter forums. A number of student activities were also initiated to convey student reaction and dissatisfaction including a petition with 1,000 plus signatures (Madden, 2013) along with the staging of a tiny peaceful protest by UWI students in Bridgetown on September 13, 2013 (Gilkes, 2013; Joseph, 2013). Additionally, UWI administrators have been actively engaged in extensive consultation with its student body and staff over the past two years and information has been communicated to students about costs for the academic year 2014-2015 via the university's website, email communication, and various other forums such as town hall meetings. As a result, information on the cost of UWI education has been relatively well publicized, particularly since August 2013.

\section{Literature Review}

A review of the literature reveals that although an abundance of scholarly literature exists on the returns to investment of university education (see Psacharopoulos \& Patrinos, 2002; GOV.UK., 2010; PayScale, Inc. 2013), very sparse research actually exists that examines the extent of students' knowledge on the issue of "cost of university education". Moreover, as far as the researchers are aware, no published Caribbean research had been done to ascertain UWI students' knowledge on this topic. The lack of global research on university students' knowledge on this topic may be partially explained by the fact that in many countries students cover their university costs by one or a combination of methods such as parental financial support, student loans (Bradford, 2013), student on or off campus work-study programmes (see U. S. Department of Education, 2013), or scholarships/financial aid awards (Council of Ontario Universities, 2012; GOV.UK., 2010; Greenburg, 2011). Furthermore, decisions to pursue university education are generally made long before actual admission to a university - usually during the students' senior year in high school. Thus, for many, it is at this stage that parents/guardians and students commence navigation of potential university choices and fill out applications (Own Your Own Future, 2014). The process of gathering information on university costs is generally accomplished by undertaking a substantial amount of individual personal research primarily through perusal of university websites which provide very detailed breakdown of costs, scholarship opportunities etcetera. Consequently, in light of the various methods aforementioned, both students and their parents/guardians in other countries generally become relatively knowledgeable about the full financial implications of university educational costs long before entry into a university. 
Accordingly, the samples used in research conducted to date which examined knowledge/awareness on costs associated with university education were done using pre-university students and/or their parents/guardians-rather than actual university students (see George-Jackson \& Gast, 2015). Notwithstanding, these studies will still provide useful and informative insight on knowledge/awareness of education costs in general which can be used as a reference for this study.

\subsection{Knowledge and Awareness of Costs of Tertiary Education and Other Important Issues in Education}

Several studies conducted globally that examined knowledge/awareness on various issues related to higher education noted that respondents were not very well informed and in fact had large gaps in knowledge. More specifically, researchers found that a substantial proportion of respondents (students and parents) were uninformed, poorly informed, and/or had very inaccurate ideas on the various issues investigated. Further, they either gave unrealistic answers or could not provide an answer.

The General Accounting Office (1990) synthesis of 18 studies indicated that both "students and parents knew surprisingly little about financial aid for higher education or the costs of post-secondary education" (p. 1). More recent work documents similar findings/concerns. For example, Horn, Chen, and Chapman's (2003) study revealed that less than $15 \%$ of students and $30 \%$ of parents were able to estimate college costs. Their research noted gross under and over estimations by both students/parents (Grodsky \& Jones, 2007). Avery and Kane (2004) and Perna (2004) documented similar concerns regarding inaccurate knowledge of college costs, as did The Stanford University Bridge Project, a six-year national study using 2,103 students/parents (Kirst, 2004). Research indicates that two primary reasons identified for the inadequacy in knowledge of tertiary education costs were information inadequacy (see Commission on the Future of Higher Education, 2006), and information complexity experienced by low income and minority groups (see Grodsky \& Jones, 2007; Long \& Riley, 2007).

McGuigan, McNally, and Wyness' (2012a, 2012b) experiment in England on student awareness of costs and benefits of education decisions - effects of an information campaign, is however perhaps the most applicable study that can be used as a reference for this research. The experiment which coincided and was executed immediately after the Government's announcement that students would be subjected to a fee increase in university fees caused great public outcry which attracted considerable media publicity, particularly in light of a protest that involved tens of thousands of students and lecturers. The experiment sought to ascertain student knowledge and perceptions regarding tertiary education on five issues, namely, (1) knowledge of student finance, (2) perceived importance of financial constraint, (3) opportunity costs, (4) knowledge about the benefits of staying in education, and (5) future intentions. In light of timing of the experiment, the researchers also decided to examine the impact of media publicity on student knowledge and perceptions on the aforementioned issues. The sample comprised 54 of the 515 secondary schools in London and more than 12,000 students. The targeted population was Year 10 students in the age range of 14-15 (i.e., students who had one year more to complete their secondary education). The experiment was executed using a randomized control trial with two waves using the same participants in both waves. The students were surveyed using a 40-minute questionnaire executed under exam conditions. During the eight-twelve week period leading up to the second wave, the treatment group was given an information package that explained the costs/benefits of tertiary education; however, the control group was given the package only after completion of the second survey. The major finding from the research was that "there are substantial gaps in school students' knowledge of very basic facts about the costs and benefits of staying in education" (McGuigan, McNally, \& Wyness, 2012b, p. 14). These gaps were evident on all five aforementioned research issues, with the gaps being substantial on Issue 1 (knowledge of student finance) where student knowledge at baseline was less than 50 percent. The researchers also noted that media reporting created a negative perception, namely, that university costs were quite expensive since it focused primarily on the fee increases. In contrast, an in-school education campaign effectively reversed some of the negativity created by the media by focusing on available financing options and repayment policies - rather than fee increases. Overall, the experiment found that the targeted information campaign improved student knowledge generally (e.g., student knowledge on Issue 1 improved by an average of $6.7 \%$ ).

\subsection{Are Higher Premiums Placed on Tertiary Education When Self-Financed?}

Numerous debates have taken place globally on whether university education should be free. While many positive externalities undoubtedly accrue from free tertiary education such as a more educated and productive workforce which benefits society in general, societal equity of opportunity, and so on, questions are today being raised about whether continued free tertiary education is sustainable given our tough economic times and numerous competing claims on limited fiscal resources. An important question in this debate is whether students value education more when personally self-financed. Immerwahr's (2004) research for The National Center for Public Policy and Higher 
Education revealed that approximately $74 \%$ of all respondents in four separate studies conducted between 1993 and $2003(1993=76 \%, 1998=77 \%, 2000=74 \%, 2003=69 \%)$ felt that "students appreciate the value of a college education only when they have some personal responsibility for paying what it costs" (p. 9). Similar sentiments have also been expressed by Pettinger (2014) who noted that free university education tends to encourage students to take an easy few years of relaxation. Comparatively, when individuals self-finance their education, they generally tend to place a higher premium on the value of their education.

\subsection{Opportunity Costs Associated with Tertiary Education}

Historically, society has supported development of its citizenry through widespread availability and public subsidization of education at primary, secondary, and tertiary levels on the grounds that education is pivotal to human capital development in a country (Cohen, 2003; Department of Treasury, 2012) and that the public expenditure on education is adequately recovered over the longer term through higher tax revenues from the more educated, and savings on social services such as Medicare since educated individuals generally tend to make better informed health decisions (Organisation for Economic Co-operation and Development, 2012). The past two decades has however witnessed substantial changes to education policies globally, particularly at the tertiary level. These changes have been triggered by two major issues, namely, (1) fiscal pressures facing countries, coupled with numerous competing demands on the limited financial resources available, and (2) fundamental shifts in philosophical thinking that education of the populace provides high personal benefits which far outweigh societal benefits (Borland, Dawkins, Johnson, \& Williams, 2000; Cohen, 2003; Department of Treasury, 2012). As a result of these policy changes, many individuals are today paying the full cost or at least partial costs of their tertiary education costs (Pettinger, 2014). Regardless of who pays the cost of tertiary education, the pursuit of tertiary education carries significant opportunity costs-pecuniary and non-pecuniary.

Numerous definitions abound for opportunity costs. The New Zealand Treasury (2005) defines opportunity costs as the "next best alternative that must be given up in order to take up the opportunity" (p. 15), HM Treasury (2007) defines it as "the value of the most valuable of alternative uses (p. 33), while Encyclopedia of Management (2009) defines it as "the value of a forgone activity or alternative when another item or activity is chosen" (II1). Although these definitions are quite neutral in that the word "financial" is not included in any of the definitions, most individuals tend to think of opportunity costs purely in financial terms. As such, much of the research that has been conducted on opportunity costs has tended to quantify opportunity costs in dollars and cents. For example, Abel and Deitz's (2014) study which examined whether the benefits of college outweigh the costs found that despite rising costs and falling wages, the personal return on investment of a bachelor's degree over a high school diploma was at least $15 \%$. In computing the return on investment, direct costs (e.g., tuition fees) and opportunity costs (wages forgone as a result of full-time college attendance) were taken into account. In this study, opportunity costs were examined from the individual or private perspective, that is, the wages given up whilst attending college full-time. However, opportunity costs can also be considered from the societal or public perspective. For instance, Pettinger's (2014) article which examined both the pros and cons of free university education identified public opportunity costs as an argument against free education. In other words, when a country channels funds into tertiary education, less can be spent on other desirable social services. "The cost of higher education to government is the opportunity cost of public expenditure on it....the value of expenditure on the next best alternative" (Borland et al., 2000, p. 30).

In addition to the monetary opportunity costs which are given up when one pursues tertiary education which can be both private (lost earnings) and public (alternative use of a country's fiscal resources), there are other types of opportunity costs which are given up in the pursuit of the higher educational endeavor. These include forgone work experience whilst studying, and the activities given up in lieu of studies (Encyclopedia of Management, 2009).

\section{Methodology}

\subsection{Sample}

The sampling frame was undergraduate Barbadian students enrolled in the FSS, UWI, Cave Hill Campus. FSS was selected since it has the largest student enrollment (approximately 60\% of total student population) at the University and the fee structure in this Faculty is similar to two other Faculties at the institution (see Table 1).

The sampling methodology employed was purposive sampling. One hundred and twenty-five students were selected but only 93 useable surveys were obtained. While this sample is quite small, it nonetheless exceeded the minimum sample size requirements needed for the statistical tests conducted. According to Harrison and Brady (2004) the normal approximation is acceptable if the sample size is at least 30 . The sample comprised more females than males in keeping with UWI enrolment statistics. 


\subsection{Survey Instrument}

4.2.1 Survey Demographics. The data collection technique employed was a self-administered questionnaire (Lavrakas, 2008). The instrument was administered to participants who were asked to complete it and return it at their convenience. The questionnaire comprised two sections. Section 1 dealt with the demographic characteristics of the respondents, namely, gender (male, female), age $(<25,26-35,36-45,>45)$, current-status (full time vs. part time), and academic-status (Year 1, Year 2, Year 3).

4.2.2 Survey Questions. Section 2 comprised 11 questions aimed at gleaning insight into students knowledge/awareness/perceptions on the following issues: UWI fees, obligation of GOBD to fund UWI education, student motivation to work hard at studies given the level of investment by GOBD, student motivation to work hard at studies if university education was personally self-financed, personal opportunity costs associated with UWI education, and GOBD opportunity costs. A mixed-item survey instrument was used (9 closed-ended questions and 2 open-ended questions). Five of the closed-ended questions (questions 1, 3, 5, 7, and 11) used a nominal measurement with Yes/No responses while the remaining four questions used a ratio measurement. Question 2 employed a five category interval scale using bands of $\$ 10,000$ increments $(<\$ 10,000$ to $>\$ 40,000)$ while Questions 8, 9, and 10 used a 10-point interval scale ranging from 1 (low) to 10 (high).

4.2.3 Reliability and Validity of Instrument. An extensive literature review was conducted prior to development of the survey instrument. Face validity and content validity of the questionnaire was established by asking three experts to review/comment on the instrument. The instrument's reliability was verified by conducting a pilot test using 20 similar respondents who were asked to identify poorly worded questions and/or imprecise instructions, and also by using the Cronbach's alpha test in Statistical Package for the Social Sciences (SPSS) using the guidelines provided by Pallant (2003).

\subsection{Data Analysis}

Quantitative data analysis was conducted using SPSS (Version 16). Data was analyzed using descriptive statistics, non-parametric tests, and parametric tests. In carrying out the various statistical tests, the researchers ensured that none of the assumptions pertinent to the statistical test in question were violated. Thematic analysis was used for all qualitative data in the study.

\section{Results and Discussion}

\subsection{Sample Demographics}

The sample comprised $75 \%$ females (Female $n=70$, Male $n=23$ ). Approximately $71 \%$ of the sample was under the age of $35(<25 n=47,26-35 n=19,36-45 n=15,>45 n=11)$. Sixty-three percent of the students were part-time students (Full-time $n=34$, Part-time $n=59$ ) and the majority were final year students (Year $1 n=14$, Year $2 n=8$, Year $3 n=70$ ). This demographic profile is in keeping with the characteristics of the student population in the FSS.

\subsection{Knowledge/Awareness on UWI Education Costs}

With respect to RQ1, Table 2 shows that although $63 \%$ of our sample indicated that they knew how much it costs GOBD to finance their studies, only $36 \%$ actually selected the correct category of costs (> Barbados \$40,000). Our finding is consistent with other research (see Avery \& Kane, 2004; Grodsky \& Jones, 2007; Horn et al., 2003; Kirst, 2004; McGuigan et al., 2012b; Perna, 2004) which show surprising knowledge gaps by respondents on the issue of tertiary education costs and gross under and over cost estimations similar to our respondents.

Table 2. Knowledge/Awareness on UWI Education Costs

\begin{tabular}{llll}
\hline Question & Response & $\mathrm{n}$ & $\%$ \\
\hline $\begin{array}{l}\text { 1. Do you have any idea on how much it costs GOBD to fund your studies at the } \\
\text { Cave Hill Campus? }\end{array}$ & Yes & 56 & 63 \\
& No & 33 & 37 \\
& & \\
2. If you had to estimate the cost that GOBD is paying, how much would you & $<\$ 10,000$ & 3 & 3 \\
estimate that GOBD pays in Barbados dollars for a 3-year B.Sc. degree in the & $\$ 10,000-\$ 20,000$ & 7 & 8 \\
FSS? & $\$ 21,000-\$ 30,000$ & 20 & 23 \\
& $\$ 31,000-\$ 40,000$ & 26 & 30 \\
* Correct Category & $>\$ 40,000 *$ & 31 & 36 \\
\hline
\end{tabular}




\subsection{GOBD Obligation to Fund UWI Education}

Regarding RQ2, Table 3 indicates that more than half of the sample (66\%) were of the opinion that GOBD was under no obligation to fund their education. Our thematic analysis of the qualitative responses which asked students to provide a reason for their response on Question (3) indicates that the most common responses opinioned by students were:- (i) tertiary education should be self-financed since benefits accrue to recipient (27\%), (ii) education is expensive and fully-funded free tertiary education is no longer sustainable (11\%), and (iii) GOBD can use its funds in others sectors (8\%). Comparatively, the primary responses given for why GOBD should finance education were: (i) enhanced development of the Barbados economy (62\%), and (ii) commitment made by the GOBD on attainment of independence to provide free education to Barbadian citizens (31\%). Some verbatim responses are provided in Table 3 to support these interpretations.

Table 3. GOBD Obligation to Fund UWI Education

\begin{tabular}{llll}
\hline Question & Response & $\mathrm{n}$ & $\%$ \\
\hline 3. Do you think that that GOBD is obliged to fund your education? & Yes & 29 & 34 \\
& No & 56 & 66
\end{tabular}

4. Please provide a reason for your answer in Question 3.

Yes-Government Has Obligation To Fund

- They are obliged to fund our education because it is essential to move us from a developing nation to a developed nation.

- Free education was introduced into Barbados so all who want to further their education can do that. So free education should continue. It will benefit the country.

No-Government Has No Obligation To Fund

- If a person wants to improve themselves they should not depend on government to do so. Whilst education is important, it is expensive. It is unreasonable for the government to be obligated to pay for all students given the current economic climate.

- The government is not obliged to fund education, there are other things they can do with the money.

\subsection{Education Costs and Motivation}

RQ3 and RQ4 sought to ascertain if there were differences in motivation when education was GOBD financed compared to when education was personally financed. According to our data in Table 4, 64\% of our sample indicated that they would be motivated to work harder at their studies given the knowledge that GOBD invested approximately $\$ 104,000$ in their education. This contrasts with $80 \%$ of our total sample who indicated that they would be motivated to work harder at their studies if education was personally self-financed. The higher motivation levels when education is personally self-financed compared to when education is GOBD financed ( $80 \%$ vs. $64 \%)$ is consistent with the literature which indicates that individuals generally place a higher premium on education services which are funded from their own pockets (see Immerwahr, 2004).

Table 4. Education Costs and Motivation

\begin{tabular}{llll}
\hline Question & Response & $\mathrm{n}$ & $\%$ \\
\hline $\begin{array}{l}\text { 5. GOBD pays approximately \$104,000 for each Barbadian student for an under- } \\
\text { graduate degree in FSS. Now that you know the cost for your degree would you be } \\
\text { motivated to work harder and get a better class of degree? }\end{array}$ & No & 54 & 64 \\
& & 30 & 36 \\
$\begin{array}{l}\text { 6. Suppose you had to fund your UWI education yourself and pay what GOBD pays, } \\
\text { would you be more motivated to work harder and get a better class of degree? }\end{array}$ & Yes & 70 & 80 \\
\hline
\end{tabular}

Thematic analysis of the qualitative responses on Question 7 which asked students to provide a reason for their answer in Question 5 highlight that the two most common reasons expressed for increased motivation to succeed when education is GOBD financed were: (i) opportunity not afforded to many persons (23\%), and (ii) don't want to waste Government's money (22\%). Comparatively, the most frequent reasons provided for not being motivated when 
education is GOBD financed were: (i) difficult given competing claims on personal time (18\%), (ii) not my money-don't really care (10\%), (iii) part of our education history-Government's responsibility (8\%).

\subsection{Personal Opportunity Costs Associated with UWI Education}

RQ5 examined students' perceived personal opportunity costs associated with pursing UWI education. Opportunity costs were defined as "the cost of a forgone alternative". Regarding lost income, Table 5 shows that 59\% of our sample chose a response greater than 5. Interestingly, females tended to associate higher opportunity costs with lost income $($ Females $=66 \%$ vs. Males $=44 \%)$. This may be because women globally are today becoming increasingly important contributors to household income (Safa, 1995; Schulte, 2013) and in fact many females are now the sole breadwinners in their households (Glynn, 2012). Concerning lost time with family/friends, Table 5 indicates that $76 \%$ of our sample chose a value greater than 5 . On this question, younger students $(<25$ years) tended to select higher scores $(8-10)$. These findings appear quite logical and reasonable since younger adults would generally have less demanding responsibilities compared to older adults. This means that they would have more free time available some of which would have to be given up when studies commence. Finally, on the issue of lost leisure, Table 5 shows that $60 \%$ of our sample chose a response greater than 5. Similar to the previous question, younger students viewed lost leisure opportunities associated with studies as a greater sacrifice compared to older students.

The aforementioned findings, namely, that our sample of FSS students associate opportunity costs with lost income, lost time with family/friends, and lost leisure opportunities, are quite consistent with the literature. Abel and Deitz (2014) note that wages forgone whilst pursuing full-time tertiary education is an important consideration in the return on investment computations of tertiary education endeavours while the Encyclopedia of Management (2009) notes that opportunity costs are associated with activities that must be given up in lieu of studies.

Table 5. Personal Opportunity Costs (Measured on a Scale of 1-10)

\begin{tabular}{llllll}
\hline & $\mathrm{n}$ & \% Responses $>5$ & Mean & $\begin{array}{l}\text { Standard } \\
\text { Deviation }\end{array}$ & Mode \\
& & & & & \\
\hline Q8. Lost income & 46 & 59 & 6.46 & 3.08 & 10 \\
Q9. Lost time with family and friends & 69 & 76 & 7.23 & 2.70 & 10 \\
Q10. Lost leisure opportunities & 73 & 60 & 6.33 & 2.68 & 5 \\
\hline
\end{tabular}

\subsection{Opportunity Costs Incurred by GOBD}

Our final research question examined whether students perceived that GOBD incurred opportunity costs by sponsoring UWI education. According to our data, 68\% (Yes $n=54$, No $n=25$ ) of our sample expressed that GOBD incurred an opportunity cost by financing UWI education. Our findings therefore concur with the literature (see Borland et al., 2000; Pettinger, 2014) and suggest that most Barbadian students appreciate that GOBD can use its funds for alternative ventures.

\section{Conclusion}

\subsection{Major Findings}

Our exploratory study on students' knowledge/awareness of various facets of costs associated with their UWI education and student perceptions of State funded education revealed no statistically significant findings on our Chi-Square and ANOVA tests on any of our demographic variables. Notwithstanding, our descriptive statistics provide rich insight on FSS student perceptions/thoughts on this topic. Our major findings were: (1) less than $40 \%$ of our sample of FSS Barbadian students could correctly approximate the true costs of their UWI education, (2) more than $60 \%$ of our sample opinioned that GOBD was under no obligation to fund UWI education, (3) 16\% more of our sampled expressed that they would be motivated to work harder at their studies when education is personally self-financed compared to when it is GOBD financed, (4) more than $50 \%$ of our sample associated personal opportunity costs with lost income, lost time with family and friends, and lost leisure opportunities, and (5) 68\% of our sample felt that GOBD incurred an opportunity cost by financing UWI education.

\subsection{Implications for Policy and Practice}

Given our findings, a multifaceted harmonized approach between GOBD, UWI administration, and the Barbados media is required to properly educate and sensitize Barbadian citizens about the true costs of a UWI education. This is particularly important since many Barbadians will now have to source loans to finance the now mandatory $20 \%$ tuition fees. Any education/publicity strategy should focus not only on pecuniary costs - but also on the benefits to be derived 
from a bachelor's degree in education. In other words, the return on investment of a bachelor's degree needs to be emphasized so that Barbadians can make informed decisions.

Our data indicated that part of our sample expressed that having knowledge of the costs paid by GOBD for their UWI education did not serve as a motivator for some students to work harder at their studies. Additionally, some students expressed that GOBD did not incur an opportunity cost by financing UWI education. In light of these findings, it may be necessary for GOBD to run some short Government Information Service bulletins to help Barbadians to appreciate that education comes at a price and that GOBD has numerous competing priorities and will often need to make tradeoffs between education and other priorities. This is important because although GOBD will no longer pay 100\% of UWI education fees, the $80 \%$ that will be GOBD financed still has high associated opportunity costs for the Government.

Finally, although GOBD implemented the tuition policy because of numerous completing priorities for its limited financial resources, GOBD may need to commission a study to examine how the $20 \%$ savings by GOBD equates against the pecuniary and non-pecuniary benefits that will be lost to society from fewer university graduates to gauge the overall net effect of this decision.

\subsection{Limitations of Study and Suggestions for Future Research}

The researchers acknowledge that since our sample was purposive and selected from the FSS, that our findings are not necessarily generalizable to the wider UWI student population. Notwithstanding, our study is still very important and useful since it has contributed to the existing body of literature on the topic of knowledge/awareness of educational costs by providing additional evidence from a new policy context and a new sampling frame- UWI. Moreover, our study now provides better understanding on an important phenomenon of interest to many policy stakeholders in Barbados including UWI administration and GOBD. It also provides a useful foundation for future research on this topic at the UWI.

In light of the limitation of this study, it is recommended that future research on this topic use a random sample from the full UWI student population to permit generalization to the wider UWI, Cave Hill Campus student body. Important insight could also be gleaned by stratifying the student population by gender, age, and academic status to see whether these three demographics make a difference to students' knowledge and perceptions. Finally, it would be interesting to conduct this research at the other two campus locations in Jamaica and Trinidad and Tobago to observe if there are differences in knowledge/awareness/perceptions among the three campus locations.

\section{Acknowledgements}

We would like to thank Dr. Dwayne Devonish for his invaluable critique of the paper.

\section{References}

Abel, J. R., \& Deitz, R. (2014). Do the benefits of college outweigh the costs? Federal Reserve Bank of New York: Current Issues in Economics and Finance, 20(3), 1-11. ISSN:1936-2374.

Alleyne, D. (2006, July 02). No way out. NationNews. Retrieved from archive.nationnews.com/archive.

Avery, C., \& Kane, T. J. (2004). Student perceptions of college opportunities: The Boston COACH program. In C. M. Hoxby (Ed.), College choices: the economics of where to go, when to go, and how to pay for it (pp. 355-394). University of Chicago Press and and the National Bureau of Economic Research. http://dx.doi.org/10.7208/chicago/9780226355375.003.0009

Barbados Tourism Encyclopedia. (2014). Barbados Education and Educational Facilities. Retrieved from http://www.barbados.org/educate.htm

Borland, J., Dawkins, P., Johnson, D., \& Williams, R. (2000). Returns to investment in higher education. The Melbourne Economics of Higher Education Research Program Report No.1. Report to the Vice Chancellor, The University of Melbourne. Retrieved from https://melbourneinstitute.com/downloads/reports/rihe.pdf

Bradford, S. L. (2013, July 10). Best ways to pay for college tuition. SmartMoney. Retrieved from http://www.dailyfinance.com/best-ways-to-pay-for-college-tuition-old/

Central Intelligence Agency. (2014). The world factbook. Retrieved from https://www.cia.gov

Cohen, H. (2003). Who should pay for higher education. New York Times. Retrieved from http://www.nytimes.com/ref/college/collegespecial2/coll_aascu_povcohen.html 
Commission on the Future of Higher Education. (2006). A test of leadership: Charting the future of U.S. higher education. Washington, DC: U.S. Department of Education. Retrieved from https://www2.ed.gov/about/bdscomm/list/hiedfuture/reports/pre-pub-report.pdf

Council of Ontario Universities. (2012). A tuition framework to support access, quality, and sustainability. COU No. 873. ISBN No. 0-88799-485-7. Retrieved from https://www.library.yorku.ca/find/.../

Department of Treasury. (2012). The economics of higher education. A report prepared by the Department of the Treasury with the Department of Education. Retrieved from www.treasury.gov/.../20121212

Encyclopedia of Management. (2009). Opportunity Cost. Retrieved from Encyclopedia.com: http://www.encyclopedia.com/doc/1G2-3273100210.html

General Accounting Office. (1990). Higher education: Gaps in parents' and students' knowledge of school costs and federal aid. Washington, DC: United States General Accounting Office. Retrieved from http://www.gao.gov/products/PEMD-90-20BR

George-Jackson, C. \& Gast, M. J. (2015). Addressing information gaps: Disparities in financial awareness and preparedness on the road to college. Journal of Student Financial Aid: 44(3), 202-234. ISSN: 0884-9153

Gilkes, R. (2013, September 13). UWI students taking fees protest to the streets. The Barbados Advocate. Retrieved from www.barbadosadvocate.com

Glynn, S. J. (2012, April). The new breadwinners: 2010 update. Center for American Progress. Retrieved January 20, 2015 from https://cdn.americanprogress.org/wp- content/uploads/issues/2012/04/pdf/breadwinners.pdf

GOV.UK. (2010, November 12). Securing a sustainable future for higher education. An independent review of higher education funding and student finance. Retrieved from www.independent.gov.uk/browne-report

Greenburg, Z. (2011, September 09). How to pay for college right now. Forbes. Retrieved from http://www.forbes.com/sites/investor/2011/09/16/how-to-pay-for-college-right-now/

Griffith, J. S. (2001). The rates of return to education in Barbados. Working Paper No: 408. Retrieved from http://www.centralbank.org.bb

Grodsky. E., \& Jones, M. T. (2007). Real and imagined barriers to college entry: Perceptions of cost. Social Science Research, 36, 745-766. http://dx.doi.org/10.1016/j.ssresearch.2006.05.001

Harrison, D. A., \& Brady, A. R. (2004). Sample size and power calculations using the noncentral t-distribution. The Stata Journal, (2) 142-153. Retrieved from http://ageconsearch.umn.edu/bitstream/116234/2/sjart_st0062.pdf

Horn, L. J., Chen, X., \& Chapman, C. (2003). Getting ready to pay for college: What students and their parents know about the cost of college tuition and what they are doing to find out. (NCES 2003-030). Washington, DC: U.S. Department of Education, Institute of Education Sciences. Retrieved from http://nces.ed.gov/pubs2003/2003030.pdf

HM Treasury. (2007). The green book: Appraisal and evaluation in central government. Retrieved from http://www.hm-treasury.gov.uk/media/05553/Green_Book_03.pdf

Immerwahr, J. (2004). Public attitudes on higher education. A trend analysis, 1993 to 2003. The National Center for Public Policy and Higher Education and Public Agenda. Retrieved from http://www.highereducation.org/reports/pubatt/

Joseph, E. (2013, September 13). Protesting UWI students warn government of a long fight. Barbados Today. Retrieved from http://www.barbadostoday.bb

Kirst, M. (2004). The high school/college disconnect. Closing Achievement Gaps, 62(3), 51-55.ISSN: 0013-1784

Lavrakas, P. J. (2008). Self-administered questionnaire. In Encyclopedia of Survey Research Methods Sage Publications, Inc. http://dx.doi.org/10.4135/9781412963947

Long, B. T., \& Riley, E. (2007). Financial aid: A broken bridge to college access. Harvard Education Review, 77(1), 39-63. ISSN: 0017-8055. http://dx.doi.org/10.17763/haer.77.1.765h8777686r7357

Madden, M. (2013, August 20). UWI guild starts protest of tuition fees. NationNews. Retrieved from www.nationnews.com

McGuigan, M., McNally, S.,\& Wyness, G. (2012a). Student awareness of costs and benefits of educational decisions: Effects of an information campaign. Working Paper CEE DP 139. Houghton Street, London: London 
School of Economics, Center for the Economics of Education. Retrieved from https://www.diw.de/documents/dokumentenarchiv/17/diw_01.c.415857.de/mcnally_applied_micro_seminar_fe b2013.pdf

McGuigan, M., McNally, S., \& Wyness, G. (2012b). Student awareness of the costs and benefits of higher education. CenterPiece, 17(2), 13-19. Retrieved from http://cep.lse.ac.uk/pubs/download/cp376.pdf

Ministry of Education, Science, Technology and Innovation. (2000). Education in Barbados information handbook. Bridgetown: Barbados: The Planning and Research Section, Ministry of Education, Youth Affairs and Culture, Barbados.

Ministry of Education, Science, Technology and Innovation. (2002). The laws of Barbados: Education Act, Chapter 41. Barbados: Government Printery.

New Zealand Treasury. (2005). Cost benefit analysis premier. Wellington, New Zealand: The Treasury.

Organisation for Economic Co-operation and Development. (2012). Education indicators focus: What are the returns on higher education for individuals and countries. Retrieved from www.oecd-ilibrary.org/education/what-are-the-returns-on-higher-educati

Own Your Own Future (2014). High school parent guide: Making college the reality.Retrieved from http://www.ownyourownfuture.com/files/for_parents_section/high_school_parent_guide.pdf

PayScale, Inc. (2013). College education ROI rankings: Does a degree always pay off? Retrieved from http://www.payscale.com/college-education-value-2013

Perna, L. W. (2004). Impact of student aid program design, operations, and marketing on the formation of family college-going plans and resulting college-going behaviors of potential student. The Education Resources Institute with support from Lumina Foundation for Education.

Pettinger, T. (2014). Should university education be free. Retrieved fromhttp://www.economicshelp.org/blog/949/economics/should-university-education-be-free/

Psacharopoulos, G. \& Patrinos, H. A. (2002). Returns to investment in education: A Further Update. Policy Research Working Paper 2881, The World Bank.

Safa, H. I. (1995). The myth of the male breadwinner: Women and industrialization in the Caribbean. Boulder, CO: Westview Press.

Schulte, B. (2013, May 29). Nearly 40 percent of mothers are now the family breadwinners, report says. The Washington Post. Retrieved from http://www.washingtonpost.com/

Sinckler, P. C. (2013). The 2013 financial statement and budgetary proposals presented to the House of Assembly of Barbados.

United Nations International Bureau of Education. (2014). World data on education VII Ed. 2010/11. Retrieved from http://www.ibe.unesco.org/en/services/online-materials/world-data-on-education.html

U. S. Department of Education. (2013). Federal student aid handbook, 2013-2014. Office of Student Financial Assistance. Washington , DC : Student Financial Assistance Programs. Retrieved from http://ifap.ed.gov/fsahandbook/1314FSAHandbookComplete ActiveIndex.html

Williams, M. (2004). The economics of education: Educating for the future. Keynote address to the 14th Rudolph Goodridge Memorial Lecture and Education Awards Ceremony on December 07, 2004 at the University of the West Indies, Cave Hill. Retrieved from http://www.centralbank.org.bb/Publications/speech_7dec2004.pdf 